\title{
Inhibition of frog sciatic nerve compound action potentials by aroma-oil compounds in a manner dependent on their chemical structures
}

\author{
Sena Ohtsubo, Tsugumi Fujita, Moe Miyahara, Akitomo Matsushita, \\ Chang-Yu Jiang, Zhi-Hao Xu, and Eiichi Kumamoto \\ Department of Physiology, Saga Medical School
}

\begin{abstract}
Aroma-oil compounds derived from plants have a variety of clinical effects including local anesthesia. We have previously reported that various aroma-oil compounds reduce the peak amplitudes of fast-conducting and $\mathrm{Na}^{+}$-channel blocker tetrodotoxin-sensitive compound action potentials (CAPs) recorded from the frog sciatic nerve in a manner dependent on their chemical structures. The present study further examined this structureactivity relationship by applying the air-gap method to the frog sciatic nerve. Cyclic alcohols ((+)-borneol, (-)-borneol, $\alpha$-terpineol), chain alcohols ((-)linalool, citronellol, geraniol) and esters (bornyl acetate, geranyl acetate) reduced CAP peak amplitudes with the half-maximal inhibitory concentration (IC50) values of $1.5 \mathrm{mM}, 2.3 \mathrm{mM}, 2.7 \mathrm{mM}, 2.0 \mathrm{mM}, 0.35 \mathrm{mM}, 0.53 \mathrm{mM}$, $0.44 \mathrm{mM}$ and $0.51 \mathrm{mM}$, respectively. This IC50 value for (-)-linalool was similar to that for $( \pm)$-linalool $(1.7 \mathrm{mM})$, a value as reported previously. On the other hand, hydrocarbon ( $p$-cymene) at a high concentration such as $2 \mathrm{mM}$ reduced CAP amplitude by only $20 \%$. The efficacy sequence of the aroma-oil compounds was esters $\geqq$ alcohols $>$ hydrocarbons, and was thus consistent with one reported previously, i.e., phenols $\geqq$ aldehydes $\geqq$ esters $>$ alcohols $>$ ketones $>$ oxides $\gg$ hydrocarbons. There was a variation in IC50 value among the alcohols used; chain alcohols were more effective in inhibiting CAPs than cyclic ones. Similar IC50 values of $(-)$-linalool and $( \pm)-$ linalool and also of $(+)$-borneol and (-)-borneol indicate no difference in efficacy between the steroisomers in inhibiting CAPs. There was no correlation between IC50 value for CAP inhibition by aroma-oil compound and its octanol-water partition coefficient value. The present study confirmed that aroma-oil compounds inhibit nerve conduction in a manner specific to their chemical structures.
\end{abstract}

Keywords

Aroma-oil compound; Frog; Sciatic nerve; Conduction inhibition;

Structure-activity relationship 


\title{
アロマ精油成分による化学構造に依存した蛙坐骨神経の複合活動電位抑制
}

\author{
大坪 瀬奈 /藤田 亜美 /宮原 萌 $/$ 松下 晋大 $/$ 蒋 昌宇 $/$ 徐 志昊 $/$ 熊本 栄一 \\ 佐賀大学医学部 生体構造機能学講座 (神経生理学分野)
}

\section{はじめに}

植物由来のアロマ精油を用いたアロマテラ ピーには, 抗不安, 抗炎症, 鎮痛, 局所麻酔など の様々な効能がある 1,4)。局所麻酔でよく知られ ているラベンダー (Lavandula angustifolia) 精油 成分の作用は 1 次感覚ニューロンにおける活動 電位の伝導抑制 7,29), つまり, 電位作動性 $\mathrm{Na}^{+}$ チャネルの抑制 13,17)によると考えられている。

我々は, 最近, 様々な植物由来成分が蛙坐骨 神経から記録される電位作動性 $\mathrm{Na}^{+}$チャネル阻 害薬テトロドトキシン（TTX）感受性の複合活 動電位 (CAP) を抑制することを見出している。 例えば, 唐辛子成分カプサイシンやミント成分 メントール, さらに, これらに関連した様々な 生理活性物質の CAP 抑制作用である 9,25)。ま た, ワサビ成分アリルイソチオシアネートやシ ナモン成分シンナムアルデヒドにも同様な作用 があることを報告している15)。

さらに, 薬物による蛙坐骨神経の CAP 抑制 は, その薬物の化学構造と密接な関係があるこ とも明らかにしている。例えば, 非麻薬性オピ オイドのトラマドールとその代謝産物モノ O-デメチルトラマドール 8), オピオイド類の モルヒネ, エチルモルヒネおよびコデイン 16), デクスメデトミジンを含む様々なアドレナリン
受容体作動薬 11), 抗痤紧䓙薬のカルバマゼピン とオクスカルバゼピン 26) のそれぞれの場合で, わずかな化学構造の違いが CAP の抑制の程度 に大きく影響することを見出している。ごく最 近, アロマ精油成分による CAP 抑制には構造 活性連関があることも明らかにしている。つま り，アロマ精油成分が CAP を抑制する序列 は, フェノール類 (カルバクロール, チモール, オイゲノール) ミアルデヒド類 (シトラール, シ トロネラール) ミエステル類 (酢酸リナリル) >


ケトン類 (プレゴン, カルボン, メントン) >オ キサイド類(ローズオキシド, シネオール)》炭 化水素類 (ミルセン, リモネン) であることを発 見した ${ }^{18)}$ 。今回, さらに, この構造活性連関 を検討するために, アルコール類 $((+)$-ボルネ

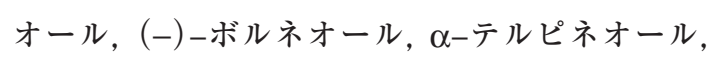
(-)-リナロール, シトロネロール, ゲラニオー ル), エステル類（酢酸ボルニル，酢酸ゲラニ ル）および炭化水素類 ( $p$-シメン) が蛙坐骨神経 の CAP にどのような作用を及ぼすか調べた。

\section{方 法}

本実験の計画は佐賀大学動物実験委員会によ 
り承認されている。

\section{1. 蛙坐骨神経標本の作製}

蛙坐骨神経標本は以前と同様な方法 9,12,15,18, 25,26)により作製した。すなわち，雌雄のトノサ マガエルから坐骨神経を摘出して実体顕微鏡下 でその表面の薄膜を注意梁く剥がし，Lucite プ レートに接着している 5 本の白金線に設置して 神経の両端を糸で結んだ。そして，神経を吊る したプレートをリンガー液が入っているビー カーに浸し，摚拌子により絶えず摚拌した。使 用したリンガー液の組成 $(\mathrm{mM})$ は, $\mathrm{NaCl}, 115.5$; $\mathrm{KCl}, 2.0 ; \mathrm{CaCl}_{2}, 1.8 ; \mathrm{Na}_{2} \mathrm{HPO}_{4}, 1.3 ; \mathrm{NaH}_{2} \mathrm{PO}$, $0.7(\mathrm{pH}=7.0)$ であった。

\section{2. 蛙坐骨神経からの複合活動電位の記録}

以前と同様 9,12,15,18,25,26), 長さが約 $3 \mathrm{~cm}$ の蛙 坐骨神経に air-gap 法を適用して CAP を記録 した。すなわち，神経の電気刺激は， 2 本の白 金線を刺激電極とし，刺激装置を用いて $1 \mathrm{~Hz}$ の頻度で $0.1 \mathrm{~ms}$ の持続時間を持つ矩形波パル スを与えることにより行った。一方，CAP の 記録は，他の 2 本の白金線を記録電極とし，増 幅器を用いて行った。このような刺激と記録 は，坐骨神経を設置した Lucite プレートを， 神経が浸らない程度の少量のリンガー液を入れ て水分で飽和状態にあるビーカーに移動させ て, 神経が乾燥しないようにして空気中で行っ た。測定は 30 秒以内に終了させ，直ちに神経 をリンガー液に戻した。このような測定を 2 分 の時間間隔で繰り返し行った。活動電位の伝導 速度 $(\mathrm{CV})$ の值は, 5 本の白金線のうちの残り の 1 本を使い刺激電極と記録電極の間の距離を 変え, 得られた CAP 波形の刺激のアーチファ クトからの潜時の変化と移動させた刺激電極の 距離の比から求めた。CAP の振幅はべースラ
インから CAP の頂点までの長さから見積もっ た。

蛙の坐骨神経には, 伝導速度の異なるいくつ かの種類の $\mathrm{A}$ 線維，また，それよりも約 60 倍 遲い CV を持つ C 線維が含まれている10)。刺 激電極と記録電極の間の距離を離すと，重なり 合った A 線維の CAP が峰別れすることが期待 されるが，使用した坐骨神経標本の長さが短い ので分離した CAP に及ぼすアロマ精油成分の

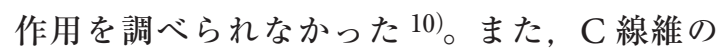
$\mathrm{CAP}$ の振幅は $\mathrm{A}$ 線維のものより大変小さいの で，C線維の CAPへの作用を検討しなかった。

\section{3. 試薬}

使用した試薬について，(+)-ボルネオール， (-)-ボルネオール，(-)-リナロール， $\alpha-$ テルピ ネオール，シトロネロール，ゲラニオール，酢 酸ゲラニルは, Sigma-Aldrich 社, L-酢酸ボル ニル（酢酸ボルニル）はフナコシ社, $p$-シメン は東京化成工業から購入した。すべての薬物 は，まずDMSO に溶かし，その後にリンガー 液に加えて使用した。DMSO 自身がCAPに 影響する可能性があるため, その濃度は $1 \%$ 以 下になるようにした。1\%の DMSO は CAP に 影響しなかった。浸透圧変化が CAP に影響す る可能性があるため, 実験に使用した試薬の濃 度は $10 \mathrm{mM}$ を最大とした。なお，試薬を溶か したリンガー液の $\mathrm{pH}$ は $1 \mathrm{~N}-\mathrm{NaOH}$ を添加し て 7.0 に調整した。

\section{4. データ解析}

試薬による CAP 振幅減少の濃度依存性は次 の Hill の式を用いて解析した。

$$
\begin{array}{r}
\text { CAP 振幅 }(\text { コントロールの相対値 })= \\
100 /\left(1+([\text { 試薬 }] / \text { IC50 })^{n_{H}}\right.
\end{array}
$$

ここで, [試薬] は試薬の濃度, IC50 は試薬が 
A



B

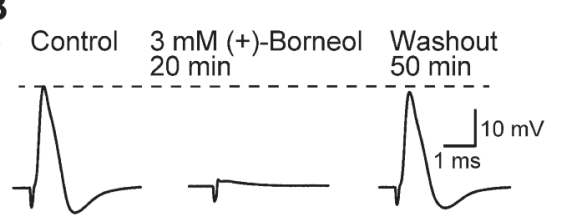

b

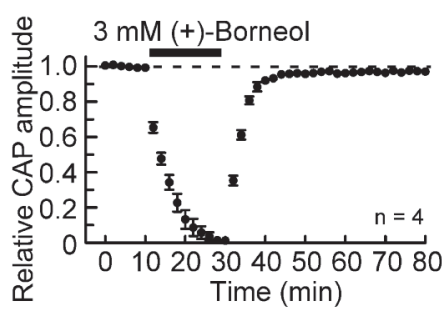

a



b

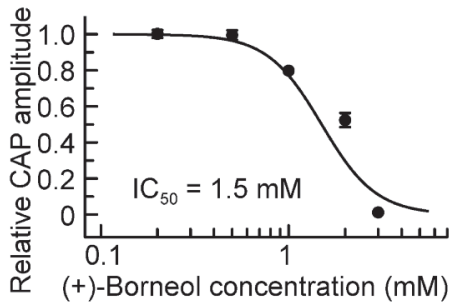

D

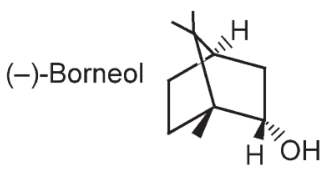

E

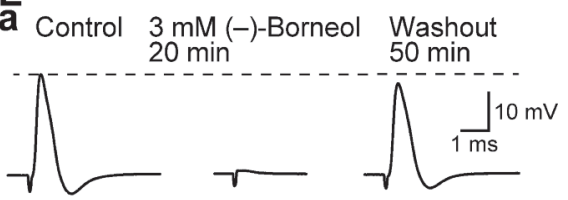

b

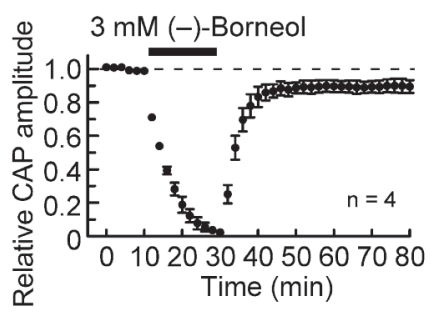

$\mathrm{F}$

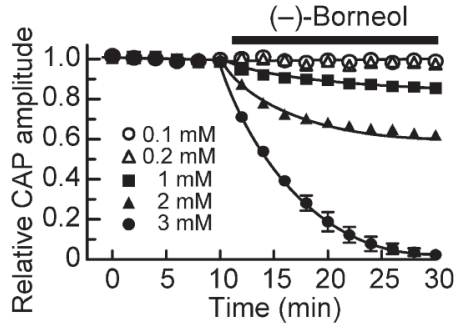

b

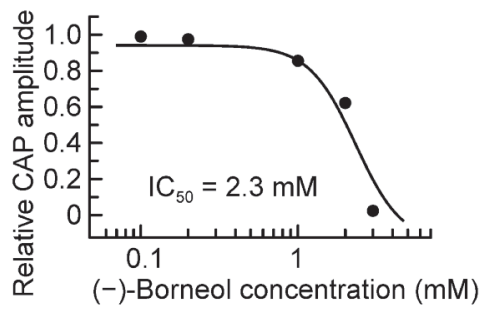

Fig.1 Cyclic alcohols, (+)-borneol and (-)-borneol, reduce the peak amplitude of compound action potential (CAP) recorded from frog sciatic nerve fibers in a concentration-dependent manner.

$(\mathrm{A}, \mathrm{D})$ The chemical structures of (+)-borneol and (-)-borneol. (B, E) (+)-Borneol and (-)-borneol (each $3 \mathrm{mM}$ ) reduce CAP peak amplitude. (Ba, Ea) Recordings of CAPs in the control (left), at $20 \mathrm{~min}$ after exposure to $(+)$-borneol or (-)-borneol (middle) and thereafter $50 \mathrm{~min}$ in the absence of $(+)$-borneol or (-)-borneol $($ right $) .(\mathrm{Bb}, \mathrm{Eb})$ Average time course of changes in CAP peak amplitude following exposure to $(+)$-borneol or (-)-borneol for $20 \mathrm{~min}$, relative to that before the soaking. In this and subsequent figures, each point with vertical bars represents the mean and S.E.M.; the S.E.M. of the values without a vertical bar was within the size of symbol. (C, F) CAP peak amplitude reductions produced by (+)-borneol or (-)-borneol at various concentrations. ( $\mathrm{Ca}, \mathrm{Fa})$ Comparison in average time course among CAP peak amplitude reductions produced by (+)-borneol at $0.2-3 \mathrm{mM}$ (obtained from $3-4$ sciatic nerves at each concentration) or by (-)-borneol at $0.1-3 \mathrm{mM}(3-4$ nerves). Solid lines in $(\mathrm{Ca})$ and $(\mathrm{Fa})$ were arbitrarily drawn. $(\mathrm{Cb}, \mathrm{Fb})$ The peak amplitude of CAP recorded from sciatic nerve fibers treated with $(+)$-borneol or $(-)$-borneol at various concentrations for $20 \mathrm{~min}$, relative to control, which was plotted against its concentration. Each of the data points was obtained from $3-4$ sciatic nerves. These solid lines were drawn by the Hill plot [half-maximal inhibitory concentration, IC50 (Hill coefficient, $\mathrm{n}_{\mathrm{H}}$ ): $1.5 \mathrm{mM}(3.0)$ and $2.3 \mathrm{mM}(2.9)$ in $\mathrm{Cb}$ and $\mathrm{Fb}$, respectively]. 
CAP 振幅を半分減少させる濃度, $\mathrm{n}_{\mathrm{H}}$ は Hill 係 数である。データは平均值 \pm 標準䛊差 (S.E.M.) で示し, 検定は Studentの $t$-testにより行い, $p<0.05$ を有意と判断した。 $n$ は調べた坐骨神 経の数である。

\section{結 果}

蛙坐骨神経の CAP の振幅は電気刺激の強度 の増加とともに増加し, その後一定值に達し た。多くの坐骨神経から得られたこの CAP の 振幅の平均值は $27.3 \pm 0.6 \mathrm{mV}(n=122)$ であっ た。また，それらの一部の坐骨神経で測定した $\mathrm{CV}$ の平均值は $28.8 \pm 1.4 \mathrm{~m} / \mathrm{s}(n=91)$ であり, これらの值は以前報告したもの 8,9,11,15,16,18,25,26) と同程度であった。今回，このような CAPに 対するアロマ精油成分の作用を調べた。

\section{1. 環状アルコール類の作用}

環状アルコールの一つであるアロマ精油成分 (+)-ボルネオール (Fig.1-A) は，ローズマリー (Rosmarinus officinalis) などに多く含まれてお り抗菌作用を持っている24)。坐骨神経を $3 \mathrm{mM}$ の $(+)$-ボルネオールを含むリンガー液に浸す と, Fig.1-Ba に示すように, CAP の振幅は減 少し，それを除去後，ほぼ完全な回復がみられ た。Fig.1-Bb は，4本の坐骨神経から得たもの で， $3 \mathrm{mM}$ の (+)-ボルネオールによる CAP の 振幅減少とその除去後の回復の平均值の経時変 化を示している。(+)-ボルネオールに 20 分間 浸した時，CAPの振幅はコントロールの $2 \pm$ $1 \%(n=4 ; p<0.05)$ まで減少した。Fig.1-Caは 0.2 3 mM の濃度範囲の $(+)$-ボルネオールを含 むリンガー液に浸した時の CAP 振幅の経時変
Table 1 Values of IC50 for frog sciatic nerve CAP peak amplitude reduction by aroma-oil compounds and of the logarithum of their Kow

\begin{tabular}{|c|c|c|c|}
\hline Group & Compound & IC50 (mM) & $\log$ Kow \\
\hline \multirow[t]{7}{*}{ Alcohols } & $(+)$-Borneol & $1.5(3.0)$ & 2.85 \\
\hline & $(-)$-Borneol & $2.3(2.9)$ & 3.01 \\
\hline & $\alpha$-Terpineol & $2.7 \quad(4.0)$ & 2.98 \\
\hline & (-)-Linalool & $2.0 \quad(2.0)$ & - \\
\hline & Citronellol & $0.35(3.1)$ & 3.91 \\
\hline & Geraniol & $0.53(3.3)$ & 3.56 \\
\hline & $( \pm)$-Linalool & $1.7 \quad(2.5)$ & 2.97 \\
\hline \multirow[t]{3}{*}{ Esters } & Bornyl acetate & $0.44(2.2)$ & 3.86 \\
\hline & Geranyl acetate & $0.51(1.1)$ & 4.04 \\
\hline & Linalyl acetate & $0.49(2.2)$ & 3.93 \\
\hline \multirow[t]{2}{*}{ Aldehydes } & Citral & $0.48(0.73)$ & 3.45 \\
\hline & Citronellal & $0.50(3.8)$ & 3.53 \\
\hline
\end{tabular}

Value in parentheses, next to IC50, indicates $\mathrm{n}_{\mathrm{H}}$ used to obtain the IC50 value in the present work. Data of $( \pm)-$ linalool, linalyl acetate, citral and citronellal were taken from Ohtsubo et al. ${ }^{18)}$.

化を示している。この振幅減少の速度は濃度の 増加とともに大きくなった。Fig.1-Cb は多くの 坐骨神経から得た結果をまとめたもので，様々 な濃度の $(+)$-ボルネオールを作用させて 20 分 後の CAP 振幅の減少を示している。この減少 の程度は濃度の増加とともに大きくなった。 Hill プロットにより解析すると, $(+)$-ボルネ オールの IC50 值は $1.5 \mathrm{mM}$ であった（Table 1)。

(-) -ボルネオール (Fig.1-D) は，（+）-ボルネ オールの光学異性体であり, (+) -ボルネオール 
A<smiles>CC1=CCC(C(C)(C)O)CC1</smiles>

B


D<smiles>CC(C)CC(C)(C)O</smiles>

E



b



$\mathbf{F}$

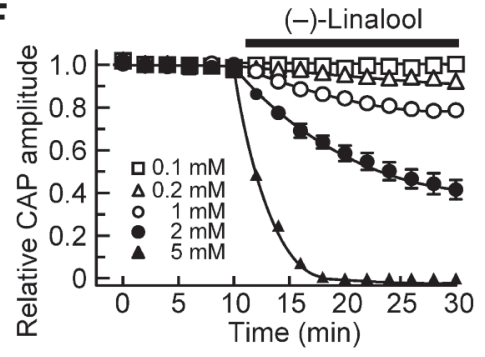

Fig.2 A cyclic alcohol $\alpha$-terpineol and a chain alcohol (-)-linalool reduce frog sciatic nerve CAP peak amplitudes in a concentration-dependent manner.

(A, D) The chemical structures of $\alpha$-terpineol and (-)-linalool. (B, E) $\alpha$-Terpineol and (-)-linalool (each $2 \mathrm{mM}$ ) reduce CAP peak amplitude. (Ba, Ea) Recordings of CAPs in the control (left), at $20 \mathrm{~min}$ after exposure to $\alpha-$ terpineol or (-)-linalool (middle) and thereafter $50 \mathrm{~min}$ in the absence of $\alpha$-terpineol or (-)-linalool (right). (Bb, $\mathrm{Eb})$ Average time course of changes in CAP peak amplitude following exposure to $\alpha$-terpineol or (-)-linalool for $20 \mathrm{~min}$, relative to that before the soaking. (C, F) Comparison in average time course among CAP peak amplitude reductions produced by $\alpha$-terpineol at $0.2-5 \mathrm{mM}$ (obtained from $3-4$ sciatic nerves at each concentration) or by (-)-linalool at $0.1-5 \mathrm{mM}(3-4$ nerves). Solid lines in (C) and (F) were arbitrarily drawn.

と同様にローズマリーなどに多く含まれてい る24)。坐骨神経を $3 \mathrm{mM}$ の (-)ーボルネオール を含むリンガー液に浸すと, Fig.1-Eaに示す ように, CAP の振幅は減少し, それの除去後, コントロールの 9 割程度までの回復がみられ た。Fig.1-Eb は，4本の坐骨神経から得たも ので, $3 \mathrm{mM}$ の (-)-ボルネオールによる CAP
の振幅減少とその除去後の部分的回復の平均值 の経時変化を示している。(-)ーボルネオールに 20 分間浸した時, CAP の振幅はコントロール の $2 \pm 2 \%(n=4 ; p<0.05)$ まで減少した。Fig.1$\mathrm{Fa}$ は 0.1 3 mM の濃度範囲の (-)-ボルネオー ルを含むリンガー液に浸した時の CAP 振幅の 経時変化を示している。この振幅減少の速度は 
A

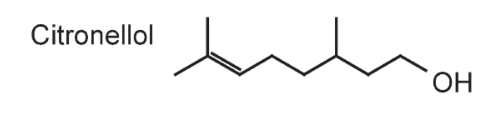

B

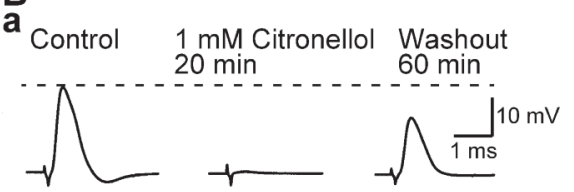

b
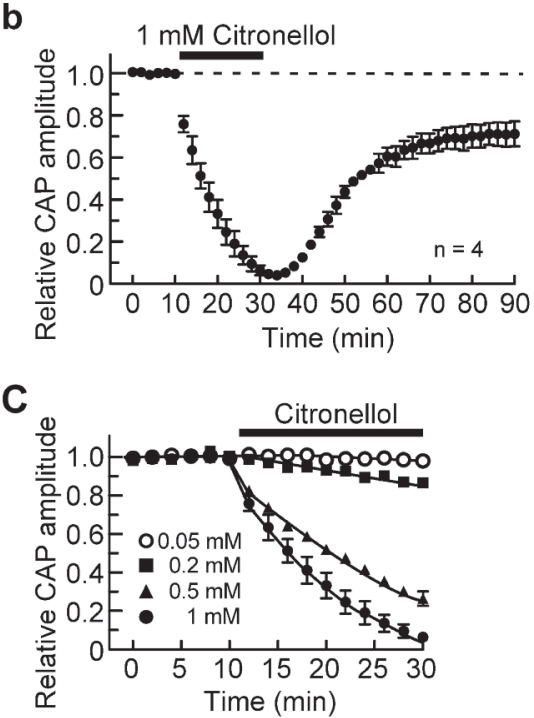

D



a

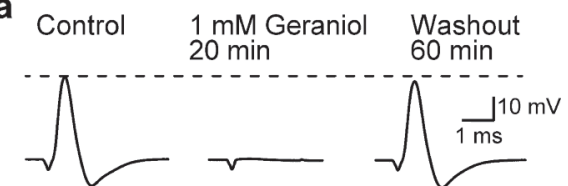

b
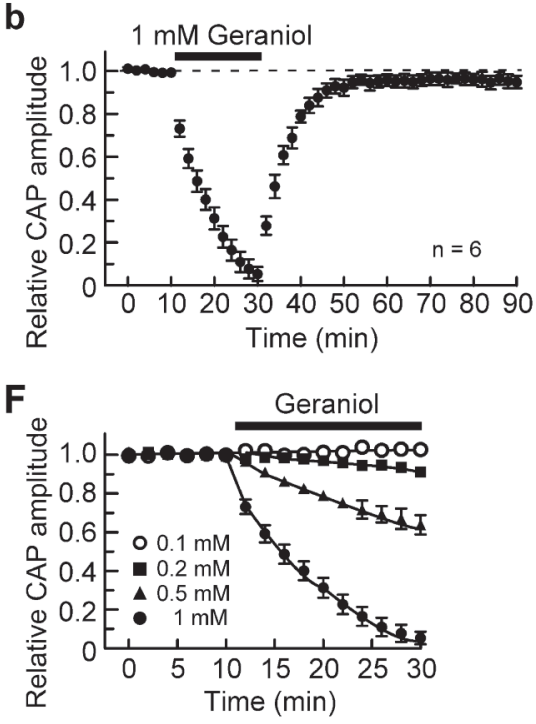

Fig.3 Chain alcohols, citronellol and geraniol, reduce frog sciatic nerve CAP peak amplitudes in a concentration-dependent manner.

(A, D) The chemical structures of citronellol and geraniol. (B, E) Citronellol and geraniol (each $1 \mathrm{mM}$ ) reduce CAP peak amplitude. (Ba, Ea) Recordings of CAPs in the control (left), at 20 min after exposure to citronellol or geraniol (middle) and thereafter $60 \mathrm{~min}$ in the absence of citronellol or geraniol (right). (Bb, Eb) Average time course of changes in CAP peak amplitude following exposure to citronellol or geraniol for $20 \mathrm{~min}$, relative to that before the soaking. (C, F) Comparison in average time course among CAP peak amplitude reductions produced by citronellol at $0.05-1 \mathrm{mM}$ (obtained from $3-4$ sciatic nerves at each concentration) or by geraniol at $0.1-1 \mathrm{mM}(3-6$ nerves). Solid lines in (C) and (F) were arbitrarily drawn.

濃度の増加とともに大きくなった。Fig.1-Fb は 多くの坐骨神経から得た結果をまとめたもので, 様々な濃度の $(-)$-ボルネオールを作用させて 20 分後の CAP 振幅の減少を示している。この減 少の程度は濃度の増加とともに大きくなった。 Hill プロットにより解析すると, (-)-ボルネ オールの IC50 值は $2.3 \mathrm{mM}$ であった（Table 1)。

ユーカリ(Eucalyptus globulus)に含まれてお り鎮痛作用を持つ環状アルコールの $\alpha$-テルピ
ネオール (2 mM; Fig.2-A $)^{22)}$ は可逆的に CAP の振幅を減少させた (Fig.2-Ba)。Fig.2-Bb は, 4 本の坐骨神経から得たもので, $2 \mathrm{mM}$ の $\alpha-$ テルピネオールによる CAP の振幅減少とその 除去後の回復の平均值の経時変化を示してい る。 $\alpha$ ーテルピネオールに 20 分間浸した時, $\mathrm{CAP}$ の振幅はコントロールの $79 \pm 4 \% \quad(n=4$; $p<0.05 ）$ まで減少した。Fig.2-C は 0.2〜 $5 \mathrm{mM}$ の濃度範囲の $\alpha$-テルピネオールを含むリン 
ガー液に浸した時の CAP 振幅の経時変化を示 している。投与 20 分後の CAP 振幅の減少の大 きさの濃度依存性を Hill プロットにより解析す ると， $\alpha-$ ルピネオールの IC50 值は $2.7 \mathrm{mM}$ であった (Table 1)。

\section{2. 鎖状アルコール類の作用}



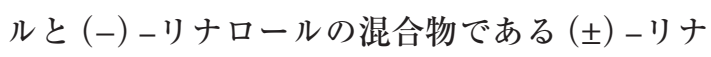
ロールの作用を調べたが 18$)$ ，今回，入手でき た (-) -リナロール (Fig.2-D) の作用を調べた。 (土)ーリナロールは，酢酸リナリルとともにラベ ンダー精油の主成分であり 7,27), これらは抗 炎症や鎮痛の作用を示す 19,20$)$ 。(-)ーリナロール $(2 \mathrm{mM})$ を含むリンガー液に坐骨神経を 20 分 間浸すと, Fig.2-Ea に示すょうに, CAP の振 幅は減少し, それを除去して 50 分後にはコン トロールの 9 割程度までの回復がみられた。

Fig.2-Eb は, 4 本の坐骨神経から得たもので, $2 \mathrm{mM}$ の (-) -リナロールによる CAP の振幅減 少とその除去後の部分的回復の平均值の経時変 化を示している。(-)-リナロールに 20 分間浸 した時, CAP の振幅はコントロールの $42 \pm$ $5 \%(n=4 ; p<0.05)$ まで減少した。Fig.2-F は 0.1 5 mM の濃度範囲の (-) -リナロールを含 むリンガー液に浸した時の CAP 振幅の経時変 化を示している。投与 20 分後の CAP 振幅の 減少の大きさの濃度依存性を Hill プロットに より解析すると，(-) -リナロールの IC50 值は $2.0 \mathrm{mM}$ であった (Table 1)。

シトロネロールは, 以前報告したシトロネ ラール18）の末端の- $\mathrm{COH}$ 基が- $\mathrm{OH}$ 基となっ ている鎖状アルコールである（Fig.3-A）。バラ （Rosa）などに多く含まれており腸管の収縮を 抑制する 23)。シトロネロール $(1 \mathrm{mM})$ を含むり ンガー液に坐骨神経を 20 分間浸すと, Fig.3-
Baに示すように, CAP は消失し, それを除去 して 1 時間後にはコントロールの 7 割程度ま での回復がみられた。Fig.3-Bbは，4本の坐 骨神経から得たもので, $1 \mathrm{mM}$ のシトロネロー ルによるCAP の振幅減少とその除去後の部分 的回復の平均值の経時変化を示している。シト ロネロールに 20 分間浸した時, CAP の振幅は コントロールの $6 \pm 2 \%(n=4 ; p<0.05)$ まで減少 した。Fig.3-C は 0.05 1 mM の濃度範囲のシ トロネロールを含むリンガー液に浸した時の CAP 振幅の経時変化を示している。投与 20 分 後の CAP 振幅の減少の大きさの濃度依存性を Hill プロットにより解析すると, シトロネロー ルの IC50 值は $0.35 \mathrm{mM}$ であった (Table 1)。

ゲラニオールはシトロネロールの炭素の単結 合の 1 つが二重結合になった構造を持っている 鎖状アルコールである（Fig.3-D）。ゼラニウム (Pelargonium graveolens) やバラなどに多く含 まれており腸管の収縮を抑制する 2,23)。ゲラニ オール (1 mM) を含むリンガー液に坐骨神経を 20 分間浸すと, Fig.3-Ea に示すように, CAP は消失し，それを除去して 1 時間後にはほぼ完 全な回復がみられた。Fig.3-Ebは，6本の坐 骨神経から得たもので, $1 \mathrm{mM}$ のゲラニオール によるCAP の振幅減少とその除去後の回復の 平均值の経時変化を示している。ゲラニオール に 20 分間浸した時, CAP の振幅はコントロー ルの $5 \pm 3 \%(n=6 ; p<0.05)$ まで減少した。 Fig.3-F は 0.1〜 1 mM の濃度範囲のゲラニ オールを含むリンガー液に浸した時の CAP 振 幅の経時変化を示している。投与 20 分後の CAP 振幅の減少の大きさの濃度依存性を Hill プロットにより解析すると, ゲラニオールの IC50 值は $0.53 \mathrm{mM}$ であった (Table 1)。 
A<smiles>CC(=O)OC1CC2(C)CCC1(C)C2</smiles>

B



b


D<smiles>CC(=O)OC/C=C(\C)CC/C=C(/C)C(Cl)(Cl)Cl</smiles>

E a Control $0.5 \mathrm{mM}$ Washout



b
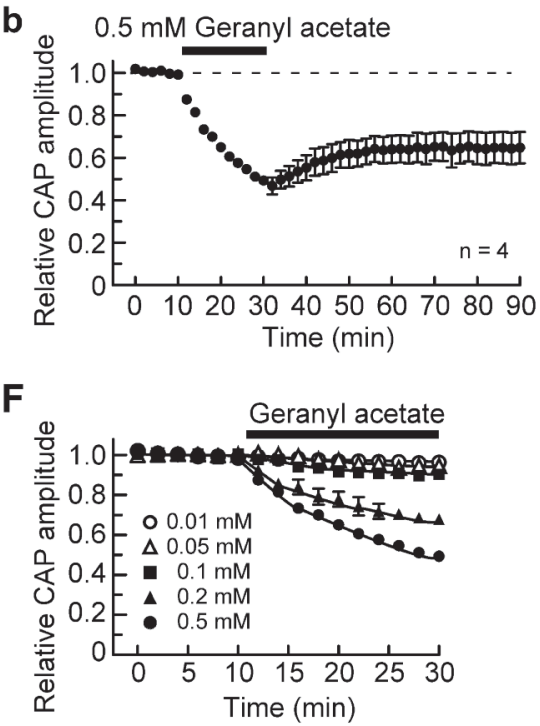

Fig.4 Esters, bornyl acetate and geranyl acetate, concentration-dependently reduce frog sciatic nerve CAP peak amplitudes in an irreversible manner.

(A, D) The chemical structures of bornyl acetate and geranyl acetate. (B, E) Bornyl acetate (1 mM) and geranyl acetate $(0.5 \mathrm{mM})$ reduce CAP peak amplitude. (Ba, Ea) Recordings of CAPs in the control (left), at $20 \mathrm{~min}$ after exposure to bornyl acetate or geranyl acetate (middle) and thereafter $60 \mathrm{~min}$ in the absence of bornyl acetate or geranyl acetate (right). (Bb, Eb) Average time course of changes in CAP peak amplitude following exposure to bornyl acetate or geranyl acetate for $20 \mathrm{~min}$, relative to that before the soaking. (C, F) Comparison in average time course among CAP peak amplitude reductions produced by bornyl acetate at $0.05-1 \mathrm{mM}$ (obtained from $3-4$ sciatic nerves at each concentration) or by geranyl acetate at $0.01-0.5 \mathrm{mM}(3-4$ nerves). The solid lines in $(\mathrm{C})$ and $(\mathrm{F})$ were arbitrarily drawn.

\section{3. エステル類の作用}

酢酸ボルニルはボルネオールの-OH 基の部 分が-OCOCH3 基となったエステル類である (Fig.4-A)。モミ(Abies firma) などに多く含ま れており自律神経の働きを緩和させる 14,28)。酢 酸ボルニル（1 mM）を含むリンガー液に坐骨神
経を 20 分間浸すと, Fig.4-Baに示すように， CAP の振幅は減少し，それを除去して 1 時間 後にはコントロールの 5 割程度までの回復がみ られた。Fig.4-Bbは，4本の坐骨神経から得 たもので, $1 \mathrm{mM}$ の酢酸ボルニルによる CAP の振幅減少とその除去後の部分的回復の平均值 の経時変化を示している。酢酸ボルニルに 20 
A
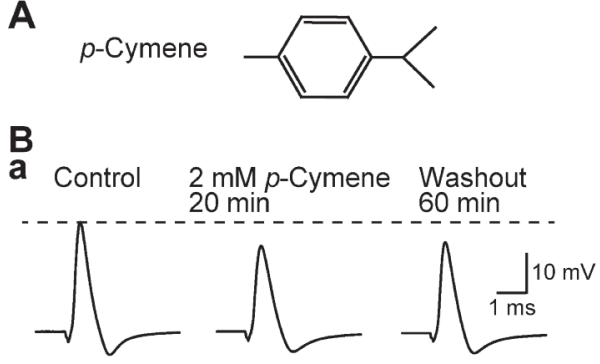

b

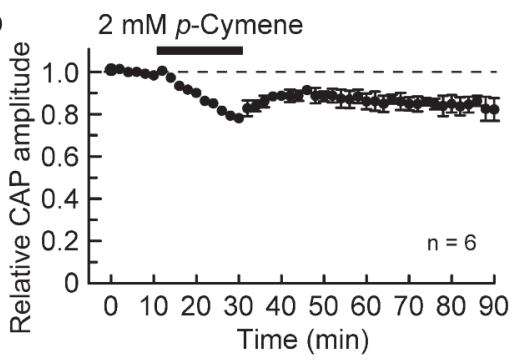

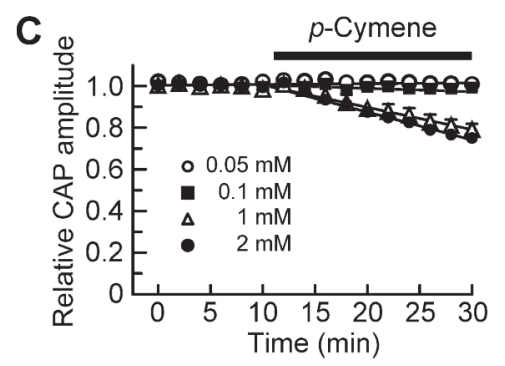

D

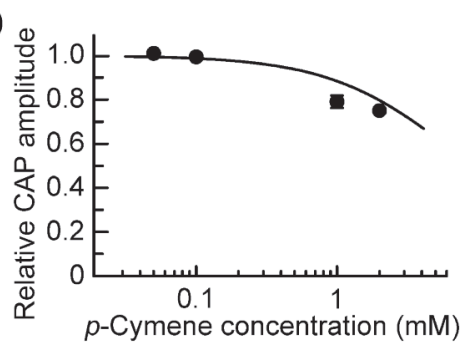

Fig.5 A hydrocarbon $p$-cymene concentration-dependently reduces frog sciatic nerve CAP peak amplitudes in an irreversible manner.

(A) The chemical structure of $p$-cymene. (B) Time course of a change in CAP peak amplitude following $p-$ cymene $(2 \mathrm{mM})$ treatment. (Ba) Recordings of CAPs in the control (left), at $20 \mathrm{~min}$ after exposure to $p$ cymene (middle) and thereafter $60 \mathrm{~min}$ in the absence of $p$-cymene (right). (Bb) Average time course of changes in CAP peak amplitude following exposure to $p$-cymene for $20 \mathrm{~min}$, relative to that before the soaking. (C) Comparison in average time course among CAP peak amplitude reductions produced by $p$-cymene at $0.05-2 \mathrm{mM}$, obtained from $3-6$ sciatic nerves at each concentration. (D) The peak amplitude of CAP recorded from sciatic nerve fibers treated with $p$-cymene at various concentrations for $20 \mathrm{~min}$, relative to control, which was plotted against its concentration. Each of the data points was obtained from $3-6$ sciatic nerves. The solid lines in (C) and (D) were arbitrarily drawn.

分間浸した時，CAP の振幅はコントロールの $36 \pm 1 \%(n=4 ; p<0.05)$ まで減少した。Fig.4-C は $0.05 \sim 1 \mathrm{mM}$ の濃度範囲の酢酸ボルニルを含 むリンガー液に浸した時の CAP 振幅の経時変 化を示している。投与 20 分後の CAP 振幅の 減少の大きさの濃度依存性を Hill プロットに より解析すると, 酢酸ボルニルの IC50 值は $0.44 \mathrm{mM}$ であった (Table 1)。

酢酸ゲラニルはゲラニオールの $-\mathrm{OH}$ 基が -OCOCH3 基となったエステル類である (Fig.4-D)。イランイラン (Cananga odorata) などに含まれており鎮痛作用を持っている 3,21 。 酢酸ゲラニル（0.5 mM）を含むリンガー液に坐
骨神経を 20 分間浸すと, Fig.4-Ea に示すよう に, CAP の振幅は減少し, それを除去して 1 時間後にはコントロールの 6 割程度までの回復 がみられた。Fig.4-Eb は，4本の坐骨神経か ら得たもので, $0.5 \mathrm{mM}$ の酢酸ゲラニルによる CAP の振幅減少とその除去後の部分的回復の 平均值の経時変化を示している。酢酸ゲラニル に 20 分間浸した時, CAP の振幅はコントロー ルの $49 \pm 2 \%(n=4 ; p<0.05)$ まで減少した。 Fig.4-F は $0.01 \sim 0.5 \mathrm{mM}$ の濃度範囲の酢酸ゲ ラニルを含むリンガー液に浸した時の CAP 振 幅の経時変化を示している。投与 20 分後の CAP 振幅の減少の大きさの濃度依存性を Hill 


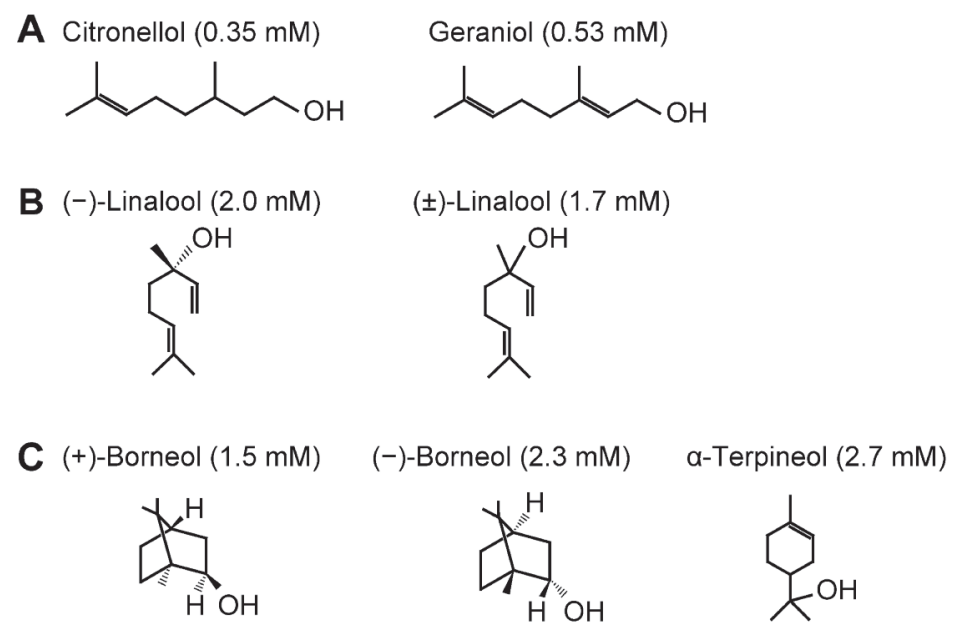

Fig.6 Relationship between the chemical structures of aroma-oil alcohols and their IC50 values in inhibiting frog sciatic nerve CAPs.

$(\mathrm{A}, \mathrm{B})$ Chain alcohols having $-\mathrm{OH}$ group at the end of the structures (A: citronellol and geraniol) and at the other positions (B: (-)-linalool and ( \pm )-linalool). (C) Cyclic alcohols ((+)-borneol, (-)-borneol and $\alpha$-terpineol). Values in parentheses indicate IC50 values. The value for $( \pm)$-linalool was taken from our previous study ${ }^{18)}$.

プロットにより解析すると, 酢酸ゲラニルの IC50 值は $0.51 \mathrm{mM}$ であった (Table 1)。

\section{4. 炭化水素類の作用}

我々は, 以前, 炭化水素類に属するアロマ 精油成分のミルセンやリモネンはCAPにほと しど作用しないことを明らかにしている 9,18)。 今回, クミン (Cuminum cyminum) やタイム (Thymus vulgaris) などのアロマ精油に含まれて おり，鎮痛作用を持つ炭化水素類 $p$-シメン （Fig.5-A） 21）が CAP に及ぼす作用を調べた。 pーシメン $(2 \mathrm{mM})$ を含むリンガー液に坐骨神経 を 20 分間浸したところ CAP のわずかな抑制 がみられ，その除去後， CAP 抑制からの部分 的な回復がみられた (Fig.5-Ba)。Fig.5-Bb は, 6 本の坐骨神経から得たもので, $2 \mathrm{mM}$ の シメンによるCAP の振幅減少とその除去後の 部分的回復の平均值の経時変化を示している。 pーシメンに 20 分間浸した時, CAP の振幅は コントロールの $78 \pm 2 \%(n=6 ; p<0.05)$ まで減
少した。Fig.5-C, D は 0.05〜2 mM の濃度範 囲のp-シメンを含むリンガー液に浸した時の CAP 振幅の経時変化と 20 分後の CAP 振幅の 減少の大きさを示している。

\section{考 察}

本研究は, アロマ精油成分による神経伝導抑 制の構造活性連関を知るために, その様々な化 学構造を持つものが蛙坐骨神経の $\mathrm{A}$ 線維に由 来するCAP に及ぼす作用を調べた。その結果, 環状アルコール類 $((+)$-ボルネオール，(-) -ボ ルネオール, $\alpha$-テルピネオール), 鎖状アル コール類 $((-)$-リナロール， シトロネロール， ゲラニオール）およびエステル類（酢酸ボルニ ル，酢酸ゲラニル）が CAP 振幅を減少させ，そ れらの IC50 值は，それぞれ $1.5 \mathrm{mM} ， 2.3 \mathrm{mM}$, $2.7 \mathrm{mM}, \quad 2.0 \mathrm{mM}, \quad 0.35 \mathrm{mM}, \quad 0.53 \mathrm{mM}, \quad 0.44$ 
$\mathrm{mM}, 0.51 \mathrm{mM}$ であることがわかった。これ らの抑制作用は, アロマ精油成分の種類により 可逆的あるいは不可逆的であったが，これらの 精油成分除去後の回復の程度の違いは蛙坐骨神 経組織への精油成分の親和性の差によるのであ ろう。一方, 炭化水素類 $(p$-シメン) は $2 \mathrm{mM}$ の濃度で約 $20 \%$ しか CAP の振幅を減少させな かった。以上より, CAP 抑制の序列は, エス テル類ミアルコール類＞炭化水素類であること が明らかになった。これは，以前報告した序 列 18) であるフェノール類 ミアルデヒド類 ミエ ステル類 $>$ ルコール類 $>$ ケトン類 $>$ オキサイ ド類》炭化水素類に含まれていた。つまり, CAP 抑制のためにはエステル基やヒドロキシ ル基（アルコール類）が重要であることが確か められた。

以上のアルコール類の IC50 值については, 0.35 2.7 mM の範囲でバラッキが大きかった。 このため, アルコール類の化学構造と CAP 抑 制の IC50 值の間に関係があるかどうかを検討 した。その結果, Fig.6で示すように, 環状ア ルコールよりも鎖状アルコールの方が, 鎖状ア ルコールの中でも $-\mathrm{OH}$ 基がその構造の端に付 いている方がそうでないものよりも IC50 值が 小さい傾向があることが明らかになった。この ことは, メントールの環が開き，かつ- $\mathrm{OH}$ 基 がその構造の端に付いているテトラヒドロラバ ンズロールの方がメントールよりも大きな CAP 抑制を示す結果と一致している15)。アル コール類と異なり, エステル類では, その構造 が鎖状であるか環状であるかは，CAPに及ぼ す作用に影響しないようであった。すなわち，

Fig.4 と Table 1 から気付かれるように, 環状 構造の酢酸ボルニルと鎖状構造の酢酸ゲラニル はほぼ同じ IC50 值を持っていた。

$$
\text { (-) -リナロールの IC50 值 }(2.0 \mathrm{mM}) \text { は, 以前 }
$$

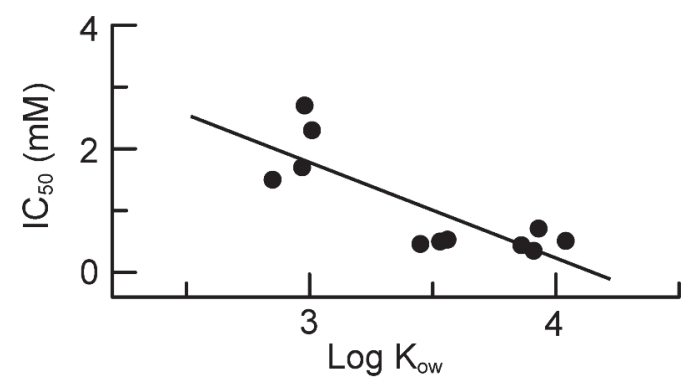

Fig.7 A relationship between the IC50 for CAP inhibition produced by aroma-oil compound and the logarithum of its octanol-water partition coefficient (Kow).

Here, are plotted data of aroma-oil compounds whose Kows are available from ChemlDplus ${ }^{5)}$ (see Table 1). The straight line drawn through the data points is the least squares regression line (correlation coefficient: 0.67 ).

報告した $( \pm)$-リナロールの IC50 值 $(1.7 \mathrm{mM}){ }^{18)}$ に近く、また, (+)-ボルネオールと (-)-ボルネ オールの IC50 值はそれほど異なっていなかっ た。つまり,リナロールとボルネオールのそれ ぞれで, 光学異性体間で伝導抑制作用にそれほ ど差はみられなかった。

-OH 基が構造の端についた鎖状アルコール 類やエステル類の CAP 抑制の IC50 值は, 局 所麻酔薬であるリドカイン，ロピバカイン，コ カインおよびレボブピバカインのもの（それら の IC50 值は，それぞれ $0.74 \mathrm{mM}, 0.34 \mathrm{mM}$,

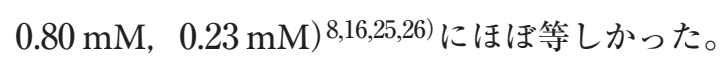
すなわち, これらの值は, 皮膚塗布により局所 麻酔作用を示すことで知られているラベンダー 精油の成分（酶酸リナリルとリナロール）の值に 匹敵していた 7,29)。つまり, 鎖状アルコールや エステルの成分を含むアロマ精油はラベンダー 精油と同程度の局所麻酔効果を持つ可能性が示 唆される。

アロマ精油成分はいずれも脂溶性であること より, CAP の抑制は細胞膜の脂質層への作用 
による可能性がある。この点を検討するため に, Fig.7で示すように，アロマ精油成分によ る CAP 振幅の減少の大きさと, その成分の脂 溶性の目安であるオクタノール-水分配係数の 間の関係を調べた。その結果，両者の間に強い 相関がみられないことがわかった。つまり，ア ロマ精油成分による CAP 抑制は, その脂溶性 とは無関係であることが明らかになった。 蛙坐骨神経の CAP が電位作動性 $\mathrm{Na}^{+}$チャネ ルの活性化を介していることは，それの TTX 感受性から明らかである8,16)。リナロールをは じめとする多くのアロマ精油成分が電位作動性 $\mathrm{Na}^{+}$チャネルを抑制することから, その成分に

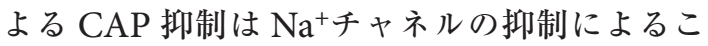
とが考えられる6,13,17)。

\section{結語}

アロマ精油成分による CAP 抑制にその特異 的な化学構造が重要であることが確かめられ た。その抑制の大きさとアロマ精油成分の脂溶 性を比較したところ, それらの間で強い相関が なかった。アロマ精油による局所麻酔あるいは 鎮痛の作用に活動電位の伝導抑制が寄与してい ると考えられるが, 本研究で明らかになった結 果は, より有効な作用を持つアロマ精油成分を 知るのに役立つかもしれない。

\section{文 献}

1) Almeida, R.N., Navarro, D.S., Barbosa-Filho, J.M., Plants with central analgesic activity, Phytomedicine, 8 (2001) 310-322.

2) Banthorpe, D.V., Le Patourel, G.N.J., Francis, M.J.O., Biosynthesis of geraniol and nerol and their $\beta-\mathrm{D}-$ glucosides in Pelargonium grave- olens and Rosa dilecta, Biochem. J., 130 (1972) 1045-1054.

3) Brokl, M., Fauconnier, M.-L., Benini, C., Lognay, G., du Jardin, P., Focant, J.-F., Improvement of ylang-ylang essential oil characterization by GC $\times$ GC-TOFMS, Molecules, 18 (2013) 1783-1797.

4) Buchbauer, G., Jirovetz, L., Aromatherapy use of fragrances and essential oils as medicaments, Flavour Frag. J., 9 (1994) 217-222.

5) ChemIDplus [Internet] Bethesda (MD): National Library of Medicine (US). Available from: http:// chem.sis.nlm.nih.gov/chemidplus/chemidlite.jsp

6) de Araújo, D.A.M., Freitas, C., Cruz, J.S., Essential oils components as a new path to understand ion channel molecular pharmacology, Life Sci., 89 (2011) 540-544.

7) Ghelardini, C., Galeotti, N., Salvatore, G., Mazzanti, G., Local anaesthetic activity of the essential oil of Lavandula angustifolia, Planta Med., 65 (1999) 700-703.

8) Katsuki, R., Fujita, T., Koga, A., Liu, T., Nakatsuka, T., Nakashima, M., Kumamoto, E., Tramadol, but not its major metabolite (mono$\mathrm{O}$-demethyl tramadol) depresses compound action potentials in frog sciatic nerves, $\mathrm{Br}$. J. Pharmacol., 149 (2006) 319-327.

9) Kawasaki, H., Mizuta, K., Fujita, T., Kumamoto, E., Inhibition by menthol and its related chemicals of compound action potentials in frog sciatic nerves, Life Sci., 92 (2013) 359-367.

10) Kobayashi, J., Ohta, M., Terada, Y., C fiber generates a slow $\mathrm{Na}^{+}$spike in the frog sciatic nerve, Neurosci. Lett., 162 (1993) 93-96.

11) Kosugi, T., Mizuta, K., Fujita, T., Nakashima, M., Kumamoto, E., High concentrations of dexmedetomidine inhibit compound action potentials in frog sciatic nerves without $\alpha_{2}$ adrenoceptor activation, Br. J. Pharmacol., 160 (2010) 1662-1676.

12) Kumamoto, E., Mizuta, K., Fujita, T., Peripheral nervous system in the frog as a tool to examine the regulation of the transmission of neuronal information. In: J.L. Murray (Ed.), Frogs: Biology, Ecology and Uses, Nova Science Publishers, Inc., New York, 2012, pp89-106.

13) Leal-Cardoso, J.H., da Silva-Alves, K.S., Ferreira-da-Silva, F.W., dos Santos-Nascimento, T., Joca, H.C., de Macedo, F.H.P., de Albuquerque-Neto, P.M., Magalhães, P.J.C., Lahlou, S., Cruz, J.S., Barbosa, R., Linalool blocks excitability in peripheral nerves and voltage-dependent $\mathrm{Na}^{+}$current in dissociated 
dorsal root ganglia neurons, Eur. J. Pharmacol., 645 (2010) 86-93.

14) Matsubara, E., Fukagawa, M., Okamoto, T., Ohnuki, K., Shimizu, K., Kondo, R., (-)Bornyl acetate induces autonomic relaxation and reduces arousal level after visual display terminal work without any influences of task performance in low-dose condition, Biomed. Res., 32 (2011) 151-157.

15) Matsushita, A., Ohtsubo, S., Fujita, T., Kumamoto, E., Inhibition by TRPA1 agonists of compound action potentials in the frog sciatic nerve, Biochem. Biophys. Res. Commun., 434 (2013) 179-184.

16) Mizuta, K., Fujita, T., Nakatsuka, T., Kumamoto, E., Inhibitory effects of opioids on compound action potentials in frog sciatic nerves and their chemical structures, Life Sci., 83 (2008) 198-207.

17) Narusuye, K., Kawai, F., Matsuzaki, K., Miyachi, E., Linalool suppresses voltage-gated currents in sensory neurons and cerebellar Purkinje cells, J. Neural. Transm., 112 (2005) 193-203.

18) Ohtsubo, S., Fujita, T., Matsushita, A., Jiang, C.-Y., Kumamoto, E., Inhibitory actions of aroma-oil chemicals on compound action potentials in the frog sciatic nerve, Pain Res., 29 (2014) 17-30.

19) Peana, A.T., D'Aquila, P.S., Panin, F., Serra, G., Pippia, P., Moretti, M.D.L., Anti-inflammatory activity of linalool and linalyl acetate constituents of essential oils, Phytomedicine, 9 (2002) 721-726.

20) Peana, A.T., de Montis, M.G., Nieddu, E., Spano, M.T., D'Aquila, P.S., Pippia, P., Profile of spinal and supra-spinal antinociception of (-)-linalool, Eur. J. Pharmacol., 485 (2004) 165-174.

21) Quintans-Júnior, L., Moreira, J.C.F., Pasquali, M.A.B., Rabie, S.M.S., Pires, A.S., Schröder, R., Rabelo, T.K., Santos, J.P.A., Lima, P.S.S., Cavalcanti, S.C.H., Araújo, A.A.S., Quintans, J.S.S., Gelain, D.P., Antinociceptive activity and redox profile of the monoterpenes $(+)-$ camphene, $p$-cymene, and geranyl acetate in experimental models, ISRN Toxicol., 2013 (2013) 459530.
22) Quintans-Júnior, L.J., Oliveira, M.G.B., Santana, M.F., Santana, M.T., Guimarães, A.G., Siqueira, J.S., de Sousa, D.P., Almeida, R.N., a-Terpineol reduces nociceptive behavior in mice, Pharm. Biol., 49 (2011) 583-586.

23) Sadraei, H., Asghari, G., Emami, S., Inhibitory effect of Rosa damascena Mill flower essential oil, geraniol and citronellol on rat ileum contraction, Res. Pharm. Sci., 8 (2013) 17-23.

24) Tavassoli, S.K., Mousavi, S.M., Emam-Djomeh, Z., Razavi, S.H., Chemical composition and evaluation of antimicrobial properties of Rosmarinus officinalis L. essential oil, Afr. J. Biotechnol., 10 (2011) 13895-13899.

25) Tomohiro, D., Mizuta, K., Fujita, T., Nishikubo, Y., Kumamoto, E., Inhibition by capsaicin and its related vanilloids of compound action potentials in frog sciatic nerves, Life Sci., 92 (2013) 368-378.

26) Uemura, Y., Fujita, T., Ohtsubo, S., Hirakawa, N., Sakaguchi, Y., Kumamoto, E., Effects of various antiepileptics used to alleviate neuropathic pain on compound action potential in frog sciatic nerves: comparison with those of local anesthetics, Biomed. Res. Int., 2014 (2014) 540238.

27) Umezu, T., Nagano, K., Ito, H., Kosakai, K., Sakaniwa, M., Morita, M., Anticonflict effects of lavender oil and identification of its active constituents, Pharmacol. Biochem. Behav., 85 (2006) 713-721.

28) Yatagai, M., Sato, T., Terpenes of leaf oils from conifers, Biochem. Syst. Eol., 14 (1986) 469478.

29) Zalachoras, I., Kagiava, A., Vokou, D., Theophilidis, G., Assessing the local anesthetic effect of five essential oil constituents, Planta Med., 76 (2010) 1647-1653.

Address for correspondence: Eiichi Kumamoto Department of Physiology, Saga Medical School Nabeshima 5-1-1, Saga 849-8501, Japan Tel: 0952-34-2273 / Fax: 0952-34-2013

E-mail: kumamote@cc.saga-u.ac.jp 